\title{
Measuring the Needs for Medical Service in the Retirement Residential Community in Korea
}

\author{
SoIm Park ${ }^{1}$, Kyung Wook Seo ${ }^{2}$ \\ ${ }^{1}$ Division of Universal Design \& Senior Housing, Korea Research Institute of Eco-Environmental Architecture, Seoul, Korea \\ ${ }^{2}$ Department of Architecture \& Built Environment, Northumbria University, Newcastle upon Tyne, UK \\ Email: *reliving@naver.com
}

How to cite this paper: Park, S. and Seo, K.W. (2017) Measuring the Needs for Medical Service in the Retirement Residential Community in Korea. Journal of Building Construction and Planning Research, 5, 116-127.

https://doi.org/10.4236/jbcpr.2017.53009

Received: August 10, 2017

Accepted: September 26, 2017

Published: September 29, 2017

Copyright $\odot 2017$ by authors and Scientific Research Publishing Inc. This work is licensed under the Creative Commons Attribution International License (CC BY 4.0).

http://creativecommons.org/licenses/by/4.0/

\begin{abstract}
Medical facilities in retirement residential areas provide diverse medical and health-related services to retirees, and they are equipped and programed with various medical services for enhancing retirees' daily activities. To find out the current status of using medical facilities by retirees, this study surveyed retirees in their fifties, sixties, and seventies, who live in Eunpyeong-gu, Seoul. The survey data was sorted by the types of medical facilities they visit, reasons for their visit, and the types of medical facilities in a retirement residential area they would prefer to visit. The pros and cons of using private and general hospitals can be evaluated further to set up the right strategy to reconcile them; and each type of hospital can be improved by adding those missing elements that the interviewees mentioned. In the broad perspective, this indicates the need to suggest the direction of preparing residential areas that are technically planned for retirees on the basis of the analysis of Korean retirees' needs.
\end{abstract}

\section{Keywords}

Urban Retirees, Baby-Boomer, Retirement Residential Area, Neighborhood Regeneration, Age-Friendly Facility, Medical Service, Universal Design, Barrier-Free Design

\section{Introduction}

South Korea is experiencing changes in citizen members of her cities as she enters the post-aged society accompanied by her low birth rate. South Korea's urban design continues to have emphasized city renewal and regeneration, but 
perceives young generations as its main target. However, future entry into the post-aged society and the aging of baby boom generation, which is a large population group accounting for $25 \%$ of South Korean population, are working as catalysts for the exploding ratio of old population, together with low fertility (Table 1 and Table 2). After 2005, the ratio of the aged to the whole population is found to concentrate on urban areas except traditional rural areas. And the ratio of the aged to the national population also shows that far more old people reside in urban areas than rural areas. These socio-demographic problems, together with a great change in paradigms, motivate research in diverse areas, and solutions in preparation for the Homo-Hundred era have been proposed continuously. Given changes in citizens' life due to retirees' retirement as well as the problem of population aging, the change of targets in city and architecture should also be constantly recognized.

Current changes in member citizens of South Korean cities mean the change of consumer groups and the change of generations staying in space. The possibility for realizing the plan of retirement medical facilities area should be examined as an alternative medical solution in a new paradigm, and this can be achieved by analyzing their differences and characteristics, and grafting plausible architectural schemes onto the citizens' demand in urban context. Research has been carried out on this theme in various disciplinary areas to resolve the problem. The existing studies, however, have paid attention only to retirees' degenerative development, and have not considered their lifestyle. Thus, this study aims to derive the direction of plans for retirement residential areas that reflects the actual needs of urban baby-boomers. Age-friendly medical facilities are the key for neighbourhood regeneration in the post-aged society, and this will be possible by overcoming the limitations of the current conditions we will describe

Table 1. Aging speed by country.

\begin{tabular}{ccc}
\hline Country & Aging society $\rightarrow$ Aged society & Aged society $\rightarrow$ Post-aged society \\
\hline France & 115 years & 45 years \\
UK & 47 years & 37 years \\
Germany & 40 years & 37 years \\
US & 73 years & 21 years \\
Japan & 24 years & 12 years \\
South Korea & 18 years & 8 years \\
\hline
\end{tabular}

Source: Statistics Korea, 2015.

Table 2. Transition of elderly population by age cohort group.

\begin{tabular}{cccccccc}
\hline & 1970 & 1980 & 1990 & 2000 & 2005 & 2010 & 2020 \\
\hline 65 or older & 991 & 1456 & 3395 & 5357 & 4367 & 5357 & 7701 \\
80 or older & 101 & 178 & 483 & 952 & 676 & 952 & 1783 \\
B/A\% & 10.2 & 12.2 & 14.2 & 17.8 & 15.5 & 17.8 & 23.3 \\
\hline
\end{tabular}

Source: Statistics Korea, 2015. 
in the following sections.

\section{Literature Review}

\subsection{Retiree's Residential Needs for Area Moving}

The common consideration in deciding upon residential mobility is an environment for various urban facilities and services such as medical and cultural facilities, and the preferred type of housing is the detached house [1]. In addition, when selecting housing, they don't evaluate it by management expenses but by the conditions of given environment and the convenient use of medical and cultural facilities. It is obvious from Table 3 that retirees prefer to live nearer to the city when they have poor heath and live alone [2].

As in Table 4, it was pointed out by Park Hye-ji [3], Kim Jin-bong [4], and Park Hye-ri [5], except Son Sung-jin [6], that a majority of retirees are considering residential removal after retirement, and selecting suburbs, which still provide easy access to cities, as the target regions of move. From this, it is found that retirees want to move to regions of relatively low living-cost as their income declines after retirement, but they try to remain in close contact with the city, rather than going to rural areas, for the reasons of health, lonely situation, or the use of familiar environment.

\subsection{Retirement Community Linked with General Hospital: Medical Safe Housing}

"Medical safe housing" is a case study of a house that provides the convenience

Table 3. Preferred residential areas in case of residential movement.

\begin{tabular}{ccccc}
\hline Item & Farming \& fishing village & Suburb & City & Total \\
\hline $\begin{array}{c}\text { In case of good } \\
\text { health }\end{array}$ & $25.2 \%$ & $44.7 \%$ & $30.1 \%$ & $100 \%$ \\
$\begin{array}{c}\text { In case of poor health } \\
\text { In case of } \\
\text { becoming alone }\end{array}$ & $18.7 \%$ & $38.2 \%$ & $43.1 \%$ & $100 \%$ \\
\hline
\end{tabular}

Source: Hong Hyung-ock et al., "Where Do You Wish to Live after Retirement", 2004.

Table 4. Preceding studies on retirees' residential mobility and their considerations.

\begin{tabular}{ccc}
\hline \multirow{2}{*}{ Researchers } & \multicolumn{2}{c}{ Residential needs } \\
\cline { 2 - 3 } Son Sung-jin & Retaining the current house & Consideration \\
Park Hye-ji & Residential movement & $\begin{array}{c}\text { Retaining the current house } \\
\text { by reducing the cost of living } \\
\text { Kim Jin-bong }\end{array}$ \\
Park Hye-ri & Residential movement & $\begin{array}{c}\text { Natural environment, } \\
\text { medical facilities, } \\
\text { cultural facilities }\end{array}$ \\
& Residential movement & $\begin{array}{c}\text { Urban life, detached house, rural life } \\
\text { Social relationship maintenance, } \\
\text { culture \& leisure, medical, townhouse }\end{array}$
\end{tabular}


of medical services for the medically vulnerable class such as the seniors who live alone and people with disabilities who cannot move freely in their community as in Figure 1 and Figure 2. As can be seen from the Zonnestraal Sanatorium in the Netherlands, the Paimio Sanatorium in Finland, Casas Da Cidade in Portugal Lisbon, public health and hygiene are important elements for the formation of the modern public senior housing. In this type of housing, it is possible to constantly check the health condition of residents and prevent dying alone. Moreover,

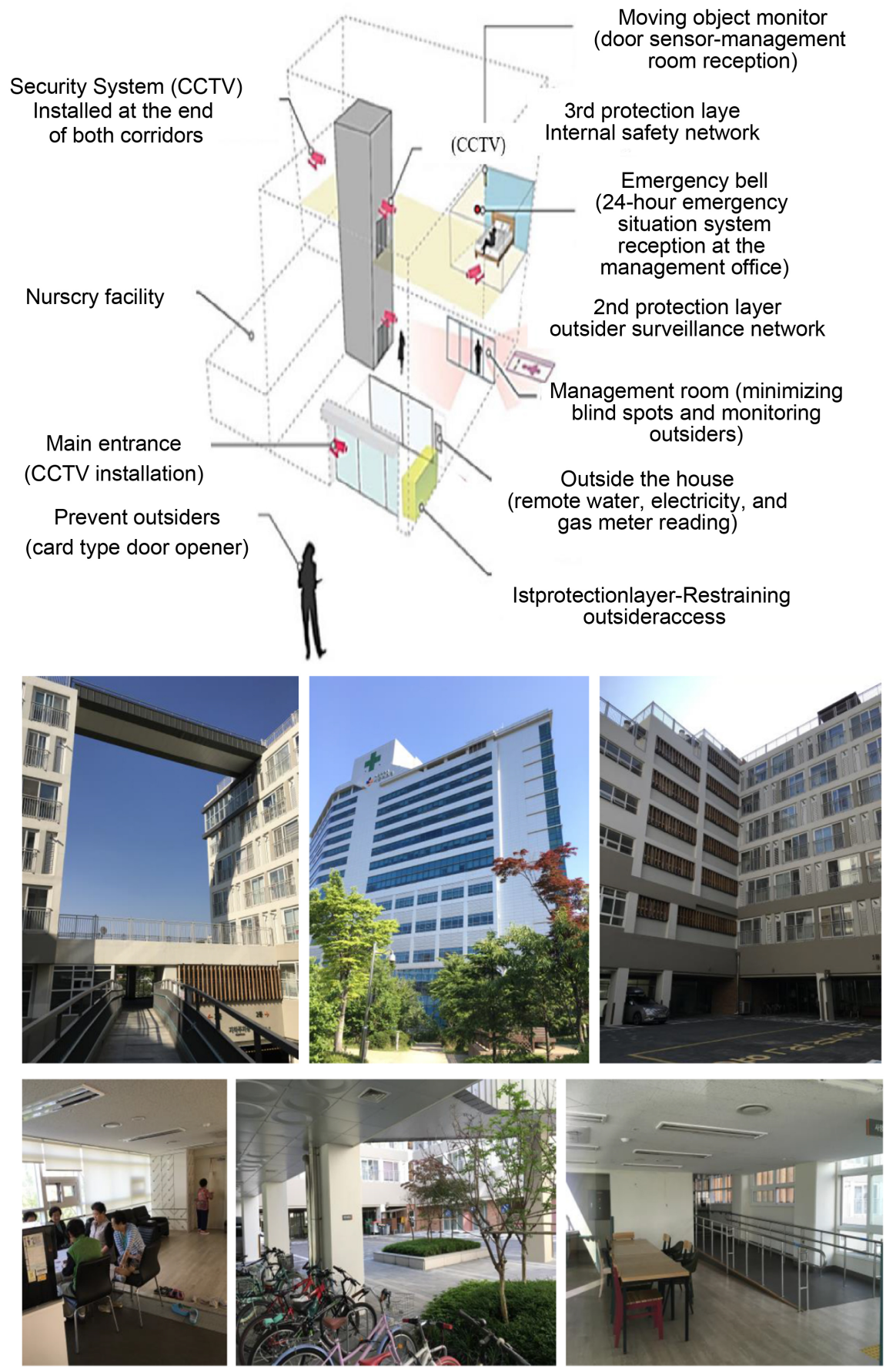

Figure 1. Medical safe housing in Seoul, South Korea. 


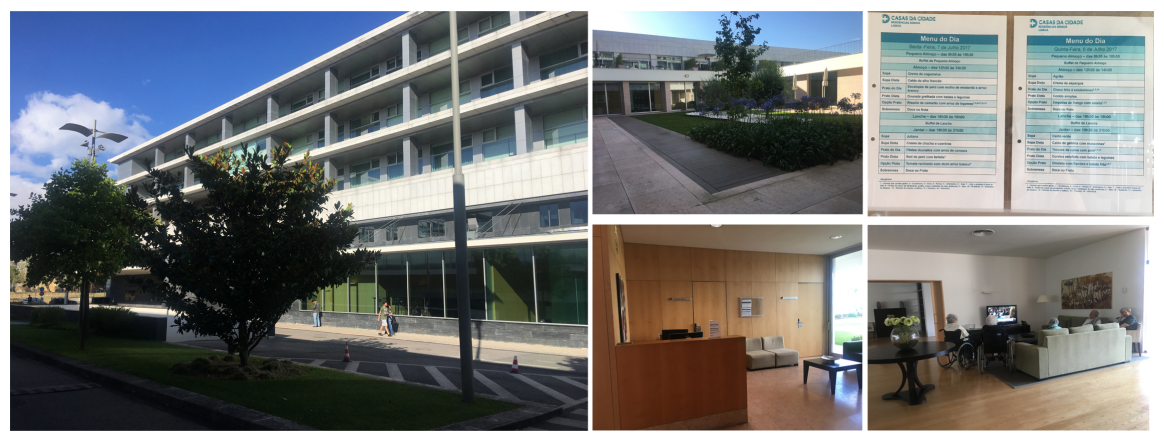

Figure 2. Medical safe housing in Lisbon, Portugal.

the inside and outside the house is designed to be "BF" (barrier-free). In other words, steps outside the house were removed for an easier access to the complex and the corridor in the building was widened so that wheelchairs could be moved in both directions freely. It gives the maximum consideration to the senior who have difficulty in moving.Medical Safe Housing is designed in accordance with the newly established guideline and it is actively linked to various ongoing services such as the care service group in the house, the home nursing system and the daycare center. In our paper, we take this concept of medical safe housing for the future development of senior retirement community.

\section{Methodology}

This study largely consists of literature review and questionnaire survey analysis. The literature review is carried out to understand the physical environment for the construction of analysis tool and to derive planning concepts; to reveal the problems of current medical facilities and retirees' life; and to analyze its scope in terms of the medical facilities of Age-friendly Residential Area for Neighborhood Regeneration. To find out the current status of using medical facilities by retirees, this study surveyed retirees in their fifties, sixties, and seventies, who live in Eunpyeong-gu, Seoul. As for the period of the pilot surveys, a total of 3 pilot surveys were carried out for 9 days from February 11 to February 20; and as for the period of the main surveys, 21 rounds of two main surveys were carried out in selected regions for 17 days from March 9 to March 26. A total of 300 questionnaires were distributed through the individual survey, group survey, and mail to find out subjects' activity characteristics. Amongst 260 questionnaires that have been returned, incomplete responses and inadequate survey subjects were excluded, and the remaining 231 copies were analyzed for this research.

Questions about the needs on medical facilities were asked in order to find the characteristics of required facilities in their current residential areas. Medical facilities in a retirement residential area refer to the facilities that are purposely planned to be integrated with residential development from the beginning. These provide diverse medical services to retirees and are equipped with various medical programs for enhancing retirees' daily activities. The survey targeted re- 
tirees in their fifties, sixties, and seventies, who live in Eunpyeong-gu, Seoul, with respect to the types of medical facilities they visit, reasons for their visit, and additionally the desired types of medical facilities in a new retirement residential area and various reasons of preferring them.

\section{Analysis of the Study}

According to the hospital regulation of Korean government, a general hospital needs to have more than 100 beds and more than 8 medical subjects with supporting doctors. In our survey, however, we noticed that interviewees regard general hospitals as those simply accommodating various types of medical subjects. With this reason, we will use the term "general hospitals" to represent any hospital operating on more than one medical subject, while "private hospitals" on only one subject. Apart from these two types of hospitals, "public health centers" are those supported by the government to provide basic services to medical problems at low cost. In Eunpyeong-gu, our sample town, there are a total of 622 medical facilities with 3550 beds. Amongst these, 12 are general hospitals with 1015 beds, 462 are private hospitals with 698 beds, and 3 are public health centers.

Table 5 shows the results of questionnaire survey on the types of medical facilities they visit frequently. The most frequent one is the private hospital $(68.0 \%)$, followed by the general hospital $(31.2 \%)$ and the public health center $(0.9 \%)$. Considering the difference in the number of general hospitals (12) and private hospitals (462), these percentages of $31.2 \%$ and $68 \%$ do not look proportional, but taking the number of beds in general hospitals (1015) and private hospitals (698) as their relative capacity of retaining patients, it is assumed that seniors tend to go to the latter more frequently for reasons other than capacity. As for desired medical facilities in a retirement residential area, the general hospital is the highest with $48.1 \%$, followed by the private hospital, $45.5 \%$ as in $\mathrm{Ta}$ ble 6. This shows that while seniors tend to visit private hospitals more often, many of them would be willing to choose general hospitals if conditions allow. It is true that in current circumstances where 12 general hospitals are scarcely located across the town while 462 private hospitals are densely located nearby

Table 5. The status of medical facilities currently being used.

\begin{tabular}{|c|c|c|c|c|}
\hline \multirow[b]{2}{*}{ Characteristics } & \multirow[b]{2}{*}{ Division } & \multirow{2}{*}{$\begin{array}{l}\mathrm{F}(\mathrm{n}=231) \\
\text { Frequency }\end{array}$} & \multicolumn{2}{|c|}{$\%$} \\
\hline & & & Valid percent & $\begin{array}{c}\text { Cumulative } \\
\text { percent }\end{array}$ \\
\hline \multirow{5}{*}{$\begin{array}{l}\text { Ownership } \\
\text { type }\end{array}$} & $\begin{array}{l}\text { Public health } \\
\text { center }\end{array}$ & 2 & 0.9 & 0.9 \\
\hline & Private hospital & 157 & 68 & 68.8 \\
\hline & General hospital & 72 & 31.2 & 100 \\
\hline & Others & 0 & 0 & \\
\hline & Subtotal & 231 & 100 & \\
\hline
\end{tabular}


Table 6. Desired medical services in a retirement residential area.

\begin{tabular}{|c|c|c|c|c|}
\hline \multirow{2}{*}{ Characteristics } & \multirow{2}{*}{ Division } & $\begin{array}{c}\mathrm{F} \\
(\mathrm{n}=231)\end{array}$ & \multicolumn{2}{|c|}{$\%$} \\
\hline & & Frequency & Valid percent & $\begin{array}{c}\text { Cumulative } \\
\text { percent }\end{array}$ \\
\hline \multirow{5}{*}{ Ownership type } & $\begin{array}{l}\text { Public health } \\
\text { center }\end{array}$ & 11 & 4.8 & 4.8 \\
\hline & Private hospital & 105 & 45.5 & 50.2 \\
\hline & General hospital & 111 & 48.1 & 98.3 \\
\hline & Others & 4 & 1.7 & 100 \\
\hline & Subtotal & 231 & 100 & \\
\hline
\end{tabular}

residences, using the former should be a challenge for various reasons. If this problem of accessibility to general hospital can be resolved through a proper town planning method for the retirement residential area, it is anticipated that there would be a stronger demand for using it.

As in Table 7, a statistical analysis was made to figure out the possible bias between gender, age and asset size in the sample group. It is found that $\mathrm{p}$ value for gender $\left(X^{2}=5.595\right)$, the age $\left(X^{2}=9.320\right)$, and the asset size $\left(X^{2}=23.646\right)$ are bigger than $0.05(\mathrm{p}>0.05)$, and thus showed no statistically significant difference.

Now, when they were asked about the reasons of using the private hospital, many of them pointed out: closer personal relationship with doctors; convenience of seeing doctors more easily and quickly; and easy accessibility (Table 8). As private hospitals outnumber general hospitals by 462 to 12 , this seems to be an expected outcome. While the answers show that slightly more retirees desire to use general hospitals (48.1\%) in a new retirement residential area as seen previously in Table 6, it is interesting to see there are still demands and preference of using private hospitals (45.5\%). The reason for this can be seen in Table 9. It is noteworthy that even after the new residential area provide better accessibility to general hospitals, the benefit of using private hospitals cannot be properly replaced.

Next, Table 10 shows the reasons for current use of general hospitals. It should be repeated that current use of general hospitals was $31.2 \%$, compared to $68 \%$ who use private hospitals. Many pulling factors for using general hospitals were related to the reliability of them due to the systematic operation and treatment of medical care as well as division of labors between many doctors and supporting staffs. In other words, respondents think the bigger hospitals generally have more advanced medical devices and operational system, combined with more professional staffs. Also, it was pointed out that with various departments in a same space, they can provide more convenient and smooth service and act promptly to emergency situations. Other answers include the convenience of parking and reservation. 
Table 7. Results from the cross-tabulation of general characteristics and desired medical services.

\begin{tabular}{|c|c|c|c|c|c|c|c|c|c|}
\hline & & \multicolumn{4}{|c|}{ Desired medical facilities to visit when sick } & \multirow[b]{2}{*}{ Overall } & \multirow[b]{2}{*}{$\mathrm{x}$} & \multirow[b]{2}{*}{ df } & \multirow[b]{2}{*}{$\mathrm{p}$} \\
\hline & & $\begin{array}{l}\text { Public } \\
\text { health } \\
\text { center }\end{array}$ & $\begin{array}{l}\text { Private } \\
\text { hospital }\end{array}$ & $\begin{array}{l}\text { General } \\
\text { hospital }\end{array}$ & Others & & & & \\
\hline \multirow{4}{*}{ Gender } & \multirow{2}{*}{ Male } & 10 & 83 & 96 & 2 & 191 & \multirow{4}{*}{5.595} & \multirow{4}{*}{3} & \multirow{4}{*}{0.133} \\
\hline & & $5.2 \%$ & $43.5 \%$ & $50.3 \%$ & $1.0 \%$ & $100.0 \%$ & & & \\
\hline & \multirow{2}{*}{ Female } & 1 & 22 & 15 & 2 & 40 & & & \\
\hline & & $2.5 \%$ & $55.0 \%$ & $37.5 \%$ & $5.0 \%$ & $100.0 \%$ & & & \\
\hline \multirow{2}{*}{\multicolumn{2}{|c|}{$50 \mathrm{~s}$}} & 3 & 55 & 56 & 3 & 117 & \multirow{6}{*}{9.320} & \multirow{6}{*}{6} & \multirow{6}{*}{0.156} \\
\hline & & $2.6 \%$ & $47.0 \%$ & $47.9 \%$ & $2.6 \%$ & $100.0 \%$ & & & \\
\hline \multirow{4}{*}{ Age } & $60 \mathrm{~s}$ & 5 & 45 & 46 & 1 & 97 & & & \\
\hline & $00 \mathrm{~s}$ & $5.2 \%$ & $46.4 \%$ & $47.4 \%$ & $1.0 \%$ & $100.0 \%$ & & & \\
\hline & \multirow{2}{*}{$70 \mathrm{~s}$} & 3 & 5 & 9 & 0 & 17 & & & \\
\hline & & $17.6 \%$ & $29.4 \%$ & $52.9 \%$ & $0.0 \%$ & $100.0 \%$ & & & \\
\hline \multirow{12}{*}{$\begin{array}{c}\text { Asset } \\
\text { size }\end{array}$} & $\begin{array}{c}\text { Less than } \\
\text { KRW } 3\end{array}$ & 1 & 6 & 9 & 0 & 16 & \multirow{14}{*}{23.646} & \multirow{14}{*}{15} & \multirow{14}{*}{0.071} \\
\hline & mil. & $6.3 \%$ & $37.5 \%$ & $56.3 \%$ & $0.0 \%$ & $100.0 \%$ & & & \\
\hline & $\begin{array}{c}\text { KRW } 300 \\
\text { mil.-less }\end{array}$ & 4 & 38 & 25 & 1 & 68 & & & \\
\hline & $\begin{array}{c}\text { than } 500 \\
\text { mil. }\end{array}$ & $5.9 \%$ & $55.9 \%$ & $36.8 \%$ & $1.5 \%$ & $100.0 \%$ & & & \\
\hline & KRW 500 & 0 & 27 & 34 & 1 & 62 & & & \\
\hline & $\begin{array}{c}\text { mil.-less } \\
\text { than } 700 \\
\text { mil. }\end{array}$ & $0.0 \%$ & $43.5 \%$ & $54.8 \%$ & $1.6 \%$ & $100.0 \%$ & & & \\
\hline & $\begin{array}{c}\text { KRW } 700 \\
\text { mil.-less }\end{array}$ & 5 & 15 & 14 & 2 & 36 & & & \\
\hline & $\begin{array}{c}\text { than } 900 \\
\text { mil. }\end{array}$ & $13.9 \%$ & $41.7 \%$ & $38.9 \%$ & $5.6 \%$ & $100.0 \%$ & & & \\
\hline & KRW 900 & 1 & 5 & 5 & 0 & 11 & & & \\
\hline & $\begin{array}{l}\text { mil.-less } \\
\text { than } \\
1200 \text { mil. }\end{array}$ & $9.1 \%$ & $45.5 \%$ & $45.5 \%$ & $0.0 \%$ & $100.0 \%$ & & & \\
\hline & KRW & 0 & 14 & 24 & 0 & 38 & & & \\
\hline & $\begin{array}{l}1200 \text { mil. } \\
\text { and over }\end{array}$ & $0.0 \%$ & $36.8 \%$ & $63.2 \%$ & $0.0 \%$ & $100.0 \%$ & & & \\
\hline \multirow{2}{*}{\multicolumn{2}{|c|}{ Overall }} & 11 & 105 & 111 & 4 & 231 & & & \\
\hline & & $4.8 \%$ & $45.5 \%$ & $48.1 \%$ & $1.7 \%$ & $100.0 \%$ & & & \\
\hline
\end{tabular}

It was already shown in Table 6 that assuming better accessibility to general hospital in a new retirement town, the proportion of choice went up to $48.1 \%$, while the choice of private hospitals went down to $45.5 \%$. For those who chose general hospitals, the same question was asked: why they hope to use general hospitals in the new setting (Table 11). It is not surprising that many of the answers are similar to the ones in the previous table due to the innate nature of 
Table 8. Reasons for using the private hospital.

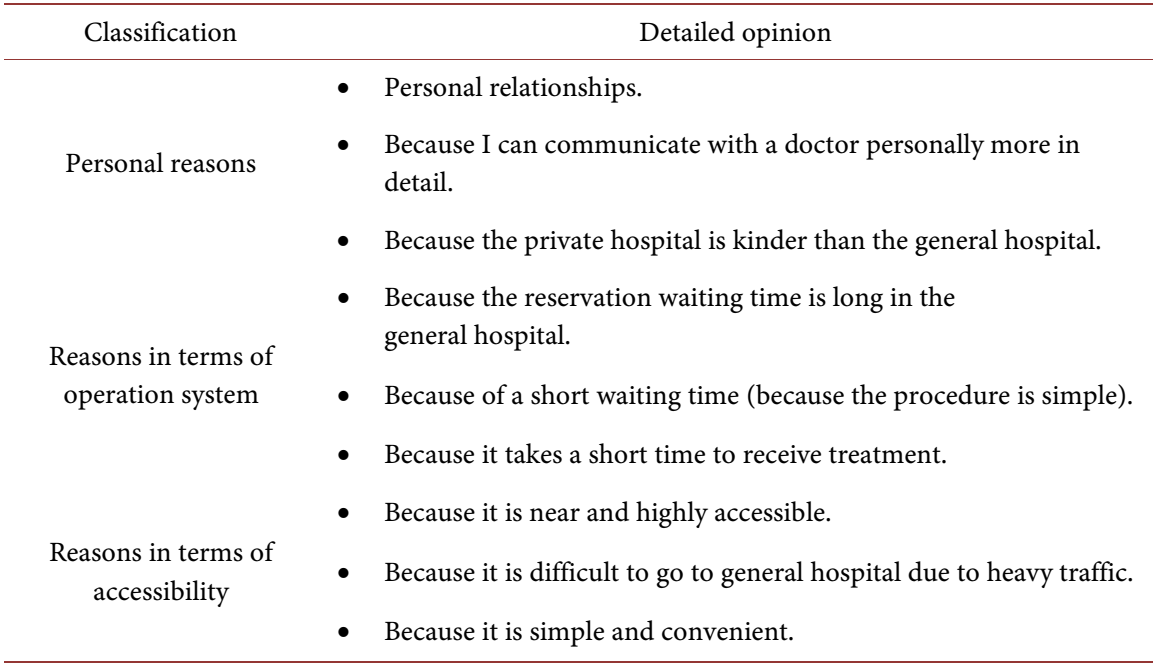

Table 9. Reasons for hoping to use the private hospital in a retirement residential area.

\begin{tabular}{|c|c|}
\hline Classification & Detailed opinion \\
\hline Personal reasons & $\begin{array}{l}\text { - Because I suppose the private hospital will provide more } \\
\text { meticulous treatment than general hospitals. } \\
\text { - Because the private hospital is kinder to patients than general } \\
\text { hospitals. } \\
\text { - Because I have personal ties with the hospital, and I suppose } \\
\text { they will give a careful care. }\end{array}$ \\
\hline $\begin{array}{c}\text { Reasons in terms } \\
\text { of system }\end{array}$ & $\begin{array}{l}\text { - Because I prefer private hospitals of a short waiting time in } \\
\text { order to receive prompt treatment. } \\
\text { - Because it is simple and convenient, and not burdensome. } \\
\text { - Because I expect they are located near. }\end{array}$ \\
\hline $\begin{array}{l}\text { Reasons in terms of } \\
\text { accessibility }\end{array}$ & $\begin{array}{l}\text { - Because it is near from my house and I can visit it any time } \\
\text { easily. } \\
\text { - I prefer a near one. }\end{array}$ \\
\hline
\end{tabular}

general hospitals. However, some different answers can be found in the last category, "reasons of physical ageing". From the answers, it is found that retired seniors are concerned about the possibility that they would get sicker, having more disease including chronic ones, and undergo a big surgery as they get older. With a constant and systematic observation on elderly people's health in their accommodation, linked with general-hospitalized care units in vicinity, the retirement residence can resolve these concerns and issues related to the accessibility of medical facilities.

Finally, Table 12 shows the reasons why they would prefer to use public health centers in the new retirement residential area. Clearly, it is the benefit of getting medical treatment in a low-cost due to the financial support from the government. It was recognized from Table 5 and Table 6, however, their proportions are very small; their percentage of current use is $0.9 \%$ and that of desired 
Table 10. Reasons for using the general hospital.

\begin{tabular}{|c|c|}
\hline Classification & Detailed opinion \\
\hline Personal reasons & $\begin{array}{l}\text { - The system is reliable. } \\
\text { - } \text { hecause the general hospital is more reliable than the private } \\
\text { - Because the medical team is reliable. } \\
\text { - Because they are kind. } \\
\text { - Because I have taken medical examinations there from the past. } \\
\text { - Because it is time I take a comprehensive medical test. } \\
\text { - Because small private hospitals have no solution. } \\
\text { - Because I can take a comprehensive medical test. } \\
\text { - Because they can provide convenient comprehensive medical } \\
\text { services. }\end{array}$ \\
\hline $\begin{array}{l}\text { Reasons in terms of } \\
\text { operation system }\end{array}$ & $\begin{array}{l}\text { - Because they provide the systematic management of my medical } \\
\text { records irrespective of specialties in medicine. } \\
\text { - Because I expect professional and specialized treatment system. } \\
\text { - Because they provide convenient reservation and parking } \\
\text { systems. }\end{array}$ \\
\hline $\begin{array}{l}\text { Reasons in terms of } \\
\text { physical facilities }\end{array}$ & $\begin{array}{l}\text { - Because of convenient parking service provided while I receive } \\
\text { diverse medical treatments. } \\
\text { - Because of far more excellent medical instruments and facilities. }\end{array}$ \\
\hline $\begin{array}{l}\text { Reasons in terms of } \\
\text { accessibility }\end{array}$ & - Because the general hospital is near from my current residence. \\
\hline
\end{tabular}

use in a retirement residential area is $4.8 \%$. The primary reason for this low usage is due to the small number of the centers in each administrative towns. In the case of Eunpyeong-gu, our sample area, there exist only three public centers while there are 12 general hospitals and 462 private hospitals. At the same time, because of their small size and limited medical service, it seems that the public health center is not considered as a proper and reliable service for serious medical problems; they are treated merely as a place for quick and easy treatments. From the 2016 statistics of Eunpyeong-gu, however, it is found that $36.3 \%$ of population over 65 has an experience of using public health centers in a given year. This indicates that there is a potential that this government supported medical system is operating well to a certain level. With more investment and expanded services, it could be an effective alternative choice for the low-income seniors in the new retirement residence.

\section{Conclusion and Discussion}

Korea has entered the aging society at an exceptional speed among OECD member countries. In addition, the retirement of the baby-boomer generation is another problem that should be solved in the era of rapid aging of population. This paper has investigated the current status and hidden preferences of the retired baby-boomer generation on their pattern of using medical facilities. The 
Table 11. Reasons for hoping to use the general hospital in a retirement residential area.

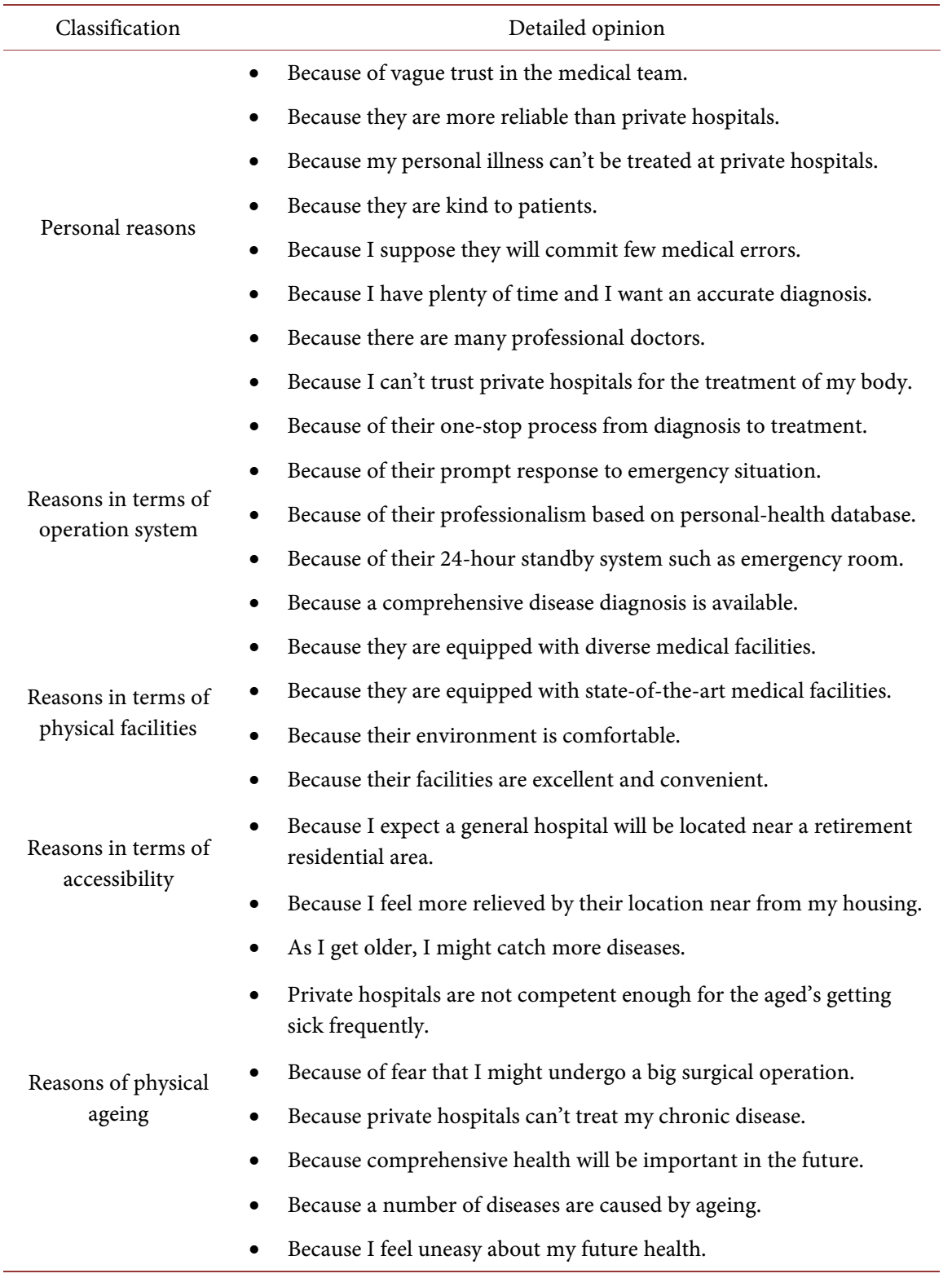

Table 12. Reasons for hoping to use public health centers in a retirement residential area.

\begin{tabular}{cl}
\hline Classification & \multicolumn{1}{c}{ Detailed opinion } \\
\hline $\begin{array}{c}\text { Financial reasons for } \\
\text { preferring the health center }\end{array}$ & $\bullet$ Because the nation offers benefits. \\
\hline
\end{tabular}

accessibility to the medical system is the key aspect in the planning of senior residences and communities, and therefore their reasons of preference was cross-checked to illuminate the possible ways of combining welcoming community with easy accessibility to medical programs. The pros and cons of using private and large hospitals can be evaluated further to set up the right strategy to reconcile them; and each type of hospital can be improved by filling in those 
missing elements that the interviewees mentioned. Furthermore, the cost issue in using medical facilities also needs to be investigated in future studies, because the frequency of using general hospitals, private hospitals and public health centers have been found to be influenced by the cost as well as accessibility. It has been reported in 2016 statistics of Eunpyeong-gu that the percentage of not getting the regular medical check due to the high-cost is the highest at the age group over 60 , compared with other lower age groups. Therefore, it is crucial to have both architectural approach and financial approach to the problem of medical care for the retired senior group and they need to be integrated to the planning of sustainable town planning for elderly people. Given the current pace of ageing of the country as a whole, the existing paradigm for housing and medical system in Korea needs to be re-evaluated and re-adapted to the emerging needs of the people and the market in the coming years.

\section{Acknowledgements}

This research has been developed from the ISAIA 2016. And Yonsei University Doctorate thesis "A Study on the Direction of Plan for Large-scale Suburban Retirement Residential Area for City Retirees" 2015 and was supported by MSIT "Ministry of Science and ICT" project "Senior Friendly Residential Area Model Development" based on the Elderly Cohort NEEDs for Promoting Local Communities and Regenerating Urban Neighborhood" 2015-2018: 2016-11-1279 as a Future of Female Scientist.

\section{References}

[1] Kim, W.-G. (2009) A Study on the Revitalization Alternatives of Welfare Housing for Senior Citizens. Master Thesis, Konyang University, Nonsan.

[2] Hong, H.O., Lee, K.H., Choi, J.S., Kim, D.N., Choi, J.S. and Kwan, O.J. (2006) Where Do You Wish to Live after Retirement? Research Center for Future Human Resources, Seoul.

[3] Park, H.J. (2014) The Desired Residential Environment after Retirement in an Aging Society: The Case of Daegu. Master's Thesis, Keimyung University, Daegu.

[4] Kim, J.B. (2013) A Study on the Characteristics and Types of Retiree's Future Housing Preference. Master's Thesis, Pusan National University, Pusan.

[5] Park, H.R. (2010) A Study on the Criterion for Choice of Future-Type Housing by Baby Boomers and the Direction for Improvement. Master's Thesis, Myong-Ji University, Seoul.

[6] Son, S.J. (2012) Study on Housing Selections Following Income Changes after Retirement of the Baby Boom Era: Focused on Seoul's Songpa-gu and Nowon-gu. Master's Thesis, Kyung-Hee University, Seoul. 
Submit or recommend next manuscript to SCIRP and we will provide best service for you:

Accepting pre-submission inquiries through Email, Facebook, LinkedIn, Twitter, etc. A wide selection of journals (inclusive of 9 subjects, more than 200 journals)

Providing 24-hour high-quality service

User-friendly online submission system

Fair and swift peer-review system

Efficient typesetting and proofreading procedure

Display of the result of downloads and visits, as well as the number of cited articles Maximum dissemination of your research work

Submit your manuscript at: http://papersubmission.scirp.org/

Or contact jbcpr@scirp.org 